\title{
Ripening Development and Quality of Melting and Non-melting Flesh Peach Cultivars
}

\author{
Ming-Wei S. Kao', Jeffrey K. Brecht, Jeffrey G. Williamson, \\ and Donald J. Huber \\ Horticultural Sciences Department, Institute of Food and Agricultural \\ Sciences, University of Florida, 1117 Fifield Hall, P.O. Box 110690, \\ Gainesville, FL 32611-0370
}

Additional index words. Prunus persica, respiration, ethylene, polygalacturonase, pectin methylesterase, freestone, clingstone

\begin{abstract}
Some physiological and biochemical properties of melting flesh (MF) and nonmelting flesh (NMF) peaches [Prunus persica $(\mathrm{L}$.$) Batsch] were determined during ripening$ for 5 days at $20^{\circ} \mathrm{C}$. Respiration rates and ethylene production of MF 'Flordaprince', MF 'TropicBeauty', NMF 'UFSun', and NMF 'Gulfking' were measured at different harvest skin ground color-based maturity stages. The MF cultivars at harvest were mostly preclimacteric or at the onset of ripening. The NMF cultivars generally had higher ethylene production at harvest and throughout ripening than the MF cultivars; thus, the NMF fruit had started ripening on the tree before harvest. Some of the NMF fruit harvested at more advanced stages quickly became postclimacteric during the storage period. Quality determination after fruit ripening showed that MF 'TropicBeauty' had the highest soluble solids content (SSC), but also the highest titratable acidity (TA). The NMF cultivars had lower TA than the MF cultivars. NMF 'Gulfking' consistently had high SSC/TA, which was the result of it having the lowest TA. The NMF cultivars retained firmer texture than the MF cultivars during ripening. The flesh firmness of the NMF cultivars was four to five times greater than that of the MF cultivars. To investigate the reason for this significant textural difference, the activities of the cell wall modification enzymes pectin methylesterase (PME) and polygalacturonase (PG) were quantified in all four cultivars at advanced ripeness stages. PME activity appeared to be more directly related with peach fruit softening than PG activity.
\end{abstract}

Melting and NMF are two main phenotypes of peach fruit and are characterized by different softening patterns in the final stage of ripening. MF cultivars carry the dominant, wild-type allele of the (M) locus that controls flesh firmness, whereas NMF cultivars possess a mutant, homozygous recessive $(\mathrm{mm})$ allele (Peace et al., 2005). MF peaches become extremely soft (i.e., "melting") quickly after ripening is triggered. Thus, they need to be harvested unripe, at a "ffirm-mature" stage, to minimize mechanical injuries, but consequently have considerably lower eating quality than tree-ripened fruit (Cascales et al., 2005; Delwiche and Baumgardner, 1983; Williamson and Sargent, 1999). NMF peaches lose firmness slowly and remain firmer even at full ripeness; thus, they should be ideal for fresh consumption because harvesting can be delayed until fruit reach a more advanced stage of ripeness.

The initiation of peach fruit ripening is accompanied by a climacteric surge of respiration and ethylene production and the peaks of both can occur simultaneously (Amoros et al., 1989; Ferrer et al., 2005). MF fruit are

Received for publication 19 Jan. 2012. Accepted for publication 13 Apr. 2012.

${ }^{1}$ To whom reprint requests should be addressed; e-mail kaoming@ufl.edu. typically harvested at the preclimacteric stage. NMF peaches can be harvested when autocatalytic ethylene production and ripening have already begun, but the ideal harvest maturity and the quality of NMF fruit have not been extensively studied. SSC is one of the most commonly used quality indicators for peaches. $\mathrm{SSC}$ in ripe peaches was reported to have a high correlation with perceived sweetness (Crisosto et al., 2006). Consumer acceptance was found to increase constantly as SSC increased (Crisosto and Crisosto, 2005). TA also plays an important role in consumer acceptance of peaches because it was found to correlate strongly with perception of sourness (Crisosto et al., 2006). TA gradually decreases as ripening progresses (Bakshi and Masoodi, 2009; Kwon et al., 2007; Moing et al., 1998), whereas SSC changes little (Robertson et al., 1991, 1992). Interaction between SSC and TA may also affect consumer acceptance of peaches and plums (Crisosto and Crisosto, 2005; Crisosto et al., 2004). For example, peaches with TA greater than 0.80 and SSC less than $10 \%$ were perceived by consumers to be of low quality (Crisosto and Crisosto, 2005; Robertson et al., 1990).

Textural changes during peach fruit ripening are achieved by the concerted action of several cell wall modification enzymes (Brummell et al., 2004; Hadfield and Bennett, 1998). Endo-polygalacturonase [endo-PG; electrical conductivity (EC) 3.2.1.15] mRNA is highly expressed after the initiation of climacteric ethylene and the increased activity is accompanied by a conversion of waterinsoluble to water-soluble pectin during the melting phase (Orr and Brady, 1993; Pressey and Avants, 1978). Because endo-PG is encoded by a multigenic family, the relatively firmer texture of ripe NMF peaches has been suggested to be the result of deletion or mutation of one or more of the members resulting in virtually no endo-PG activity (Callahan et al., 2004; Lester et al., 1994, 1996; Pressey and Avants, 1978). However, quantitative correlation between the flesh firmness and the levels of the endo-PG polypeptide has not been demonstrated (Morgutti et al., 2006). Exo-PG (EC 3.2.1.67) removes monomer units from the non-reducing end of the pectin chain and its activity increases only after extensive fruit softening for MF peaches (Downs and Brady, 1990; Orr and Brady, 1993). Exo-PG activity can be similar or higher in NMF than in MF peaches; thus, the contribution of exo-PG to texture changes during ripening of NMF peaches is also not clear (Manganaris et al., 2006; Pressey and Avants, 1973, 1978).

Before the initiation of PG-mediated pectin degradation, de-methylesterification by PME (EC 3.1.1.11) is required (Fischer and Bennett, 1991). PME activity has been shown to increase sharply at an early stage of peach ripening and remains constant or decreases throughout the melting phase in MF cultivars (Brummell et al., 2004; Glover and Brady, 1995). PME activity of NMF 'Andross' peaches was reported to be significantly lower than that of MF 'Caldesi 2000' before and after ripening (Manganaris et al., 2006). Therefore, PME activity may be related to softening of peaches more directly than endo-PG activity.

In this study, physiological and biochemical properties of MF and NMF peaches harvested during the commercial harvest period were evaluated. The objectives included 1) to determine the postharvest respiration rate and ethylene production of MF and NMF peach cultivars at various maturity stages during storage at $20{ }^{\circ} \mathrm{C} ; 2$ ) to quantify the qualities of the fruit objectively after postharvest ripening at $20{ }^{\circ} \mathrm{C}$ for $5 \mathrm{~d}$; and, $3)$ to investigate the relationship between $\mathrm{PG}, \mathrm{PME}$, and softening of MF and NMF cultivars.

\section{Materials and Methods}

\section{Plant materials}

In 2008 and 2009, two MF cultivars, Flordaprince and TropicBeauty, and two NMF cultivars, Gulfking and UFSun, were selected from the peach collection at the University of Florida Plant Science Research \& Education Center at Citra, FL. A group of 100 fruit from four trees for each cultivar were tagged after fruit thinning and natural fruit drop. These fruit were randomly selected and considered to be representative of the population of each cultivar. During later stages of fruit development, 
as the fruit approached full size, the tagged fruit were monitored visually for changes in skin ground color (GC). When the skin GC of $50 \%$ of the tagged fruit changed from green to yellow, the skin GC (CIE L*, a*, and $b^{*}$ values) of all 100 tagged fruit was objectively measured using a reflectance colorimeter (Minolta CR-400; Konica Minolta, Japan). Ground color was measured on the least advanced color portion of the skin, avoiding areas with red blush. The CIE a* value $\left(\mathrm{GCa}^{*}\right)$ was taken as representative of the degree of ripening (Delwiche and Baumgardner, 1985). Three fruit per tree (12 fruit per cultivar) with $\mathrm{GCa}^{*}$ that was within 1 SD of the 100 tagged fruit were harvested (average initial $\mathrm{GCa}^{*}=14$ ) and ripened at $20^{\circ} \mathrm{C}$ for $5 \mathrm{~d}$.

In a separate experiment, nine fruit/cultivar at more advanced ripeness stages (average initial $\mathrm{GCa}^{*}=19$ ) were collected and divided into three replications after ripening at $20^{\circ} \mathrm{C}$ for $5 \mathrm{~d}$ in 2007 and 2010 to investigate the PG and PME activities. Peach mesocarp tissue with the skin attached was collected after firmness measurements. The mesocarp tissue was diced and stored at $-30{ }^{\circ} \mathrm{C}$ until enzyme analyses were conducted.

\section{Ethylene production and respiration rate determination}

In 2008 , respiration rate $\left(\mathrm{CO}_{2}\right.$ production $)$ and ethylene production were monitored in a static system consisting of $550-\mathrm{mL}$ glass containers with airtight lids containing individual fruit that were sealed for $0.5 \mathrm{~h}$ before headspace gas samples were withdrawn for gas chromatograph (GC) injection. The $\mathrm{CO}_{2}$ was determined by injecting a $1-\mathrm{mL}$ sample into a Gow-Mac gas chromatograph (Series 580, Bridgewater, NJ) using a thermal conductivity detector (TCD) with a molecular sieve column. The carrier gas (helium) flow rate was $30 \mathrm{~mL} \cdot \mathrm{min}^{-1}$. The detector and injector were operated under ambient conditions $\left(25^{\circ} \mathrm{C}\right)$ and the oven was at $40{ }^{\circ} \mathrm{C}$. Ethylene was measured by injecting a $0.5-\mathrm{mL}$ sample into a Tracor gas chromatograph (Tremetrics, Austin, TX) with a photoionization detector and activated alumina column. The carrier gas (helium) flow rate was $40 \mathrm{~mL} \cdot \mathrm{min}^{-1}$. The detector and injector were operated at $100{ }^{\circ} \mathrm{C}$ and the oven was at $50{ }^{\circ} \mathrm{C}$. Certified gas standards (1.02\% $\mathrm{CO}_{2}$ and $1.0 \mathrm{ppm}$ ethylene) were used to determine the concentrations of $\mathrm{CO}_{2}$ and ethylene. Measured concentrations of $\mathrm{CO}_{2}$ and ethylene were converted into rates of production by calculation based on the mass of fruit in a jar, the void volume, and the duration of sealing. Respiration rate and ethylene production were monitored everyday for $5 \mathrm{~d}$ at $20^{\circ} \mathrm{C}$.

In 2009, an ETH-1010 Postharvest Gas Sensor (Model CI-900; Fluid Analytics, Inc., West Linn, OR) was used to measure respiration rate and ethylene production. This instrument uses a proprietary nanoporous, electrochemical sensor with a gold electrocatalyst. Ethylene concentration was measured with a resolution of $0.010 \mathrm{ppm}$ and $\mathrm{CO}_{2}$ concentration was measured with a resolution of $0.1 \%$. To obtain the most accurate measurement of $\mathrm{CO}_{2}$ in the headspace, the incubation time (in seconds) was recorded immediately when the concentration increased $0.1 \%$ above the initial reading. Fruit were sealed in a 2.735 -L Plexiglas container connected to the gas sensor through two Tygon tubes. After measuring each sample, the tubes were disconnected from the container, flushed with air, and connected to the next container. To minimize handling time and better control during the incubation period, the number of containers was reduced by sealing two fruit with matching ground color in one container. Fruit that had no matching counterpart were sealed individually.

\section{Quality analysis}

Skin ground color and flesh color determination. Skin ground color (GCa*) and flesh color $\left(\mathrm{FCa}^{*}\right)$ were objectively measured using a reflectance colorimeter (Minolta) and expressed as CIE a* values (green-red) because $a^{*}$ value changes the most compared with other spectral parameters with increasing maturation and ripening of peaches (Delwiche and Baumgardner, 1985) both in the skin and the flesh (Fuleki and Cook, 1976; Kader et al., 1982; Robertson et al., 1991). Ground color was measured on the least advanced color portion of the skin, avoiding areas with red blush. Flesh color was measured after removing a small (circa $2 \mathrm{~cm}$ diameter) patch of skin.

Flesh firmness determination. Flesh firmness was measured with an Instron Universal Testing Instrument (Model 4411-C8009, Canton, MA) with which a compressive force from a 50-kg load cell was applied. A convex tip probe (Magness-Taylor type), $7.9 \mathrm{~mm}$ in diameter, was attached to the load cell moving at a speed of $12 \mathrm{~cm} \cdot \mathrm{min}^{-1}$. Flesh firmness was measured at the fruit equator on opposite sides, on the cheeks, without skin, and expressed as the bioyield force $(\mathrm{N})$. After color and firmness measurements, fruit samples were placed in quart-sized $(17.7 \mathrm{~cm} \times$ $20.3 \mathrm{~cm}$ ), zipper-locking plastic freezer bags and stored at $-30{ }^{\circ} \mathrm{C}$ for later compositional analyses.

Soluble solids content, titratable acidity, and $\mathrm{pH}$. Frozen tissues $(\approx 100 \mathrm{~g})$ were partly thawed and pureed in a Waring blender for $1 \mathrm{~min}$. The resulting slurry was centrifuged $\left(20 \mathrm{~min} ; 15,000 \times \mathrm{g}_{\mathrm{n}} ; 4^{\circ} \mathrm{C}\right)$ and the clear supernatant was used to determine SSC and TA. The SSC was measured with a temperaturecompensated digital ABBE refractometer (Model Mark II; Cambridge Instruments Inc, Buffalo, NY) and expressed as percent fresh weight. The TA was determined with an automatic titrimeter (Model 719; S. Titrino, Metrohm, Switzerland) by titration of $6.0 \mathrm{~g}$ of juice plus $50 \mathrm{~mL}$ of water with $0.1 \mathrm{~N}$ sodium hydroxide solution until $\mathrm{pH} 8.2$ was reached and the TA was expressed as percent malic acid equivalents.

\section{Polygalacturonase and pectin methylesterase assays}

Preparation of cell-free protein extract. Enzyme extracts were prepared similarly to the avocado method of Jeong et al. (2002).
Partially thawed mesocarp tissue (15 g) was homogenized with $25 \mathrm{~mL}$ of ice-cold $95 \%$ ethanol for $1 \mathrm{~min}$ in an Omni Mixer homogenizer (Model GLH-01; Omni International, Kennesaw, GA) and centrifuged at 15,000 $\times$ $g_{\mathrm{n}}$ for $10 \mathrm{~min}$ at $4{ }^{\circ} \mathrm{C}$. The supernatant was discarded and the pellets were resuspended in $25 \mathrm{~mL}$ of ice-cold $80 \%$ ethanol for $1 \mathrm{~min}$ and centrifuged again at $15,000 \times g_{\mathrm{n}}$ for $10 \mathrm{~min}$ at $4{ }^{\circ} \mathrm{C}$. The pellets were transferred to $10 \mathrm{~mL}$ of $50 \mathrm{~mm}$ Na-acetate buffer, $\mathrm{pH} \mathrm{5}$, containing $0.5 \mathrm{M} \mathrm{NaCl}$, for $30 \mathrm{~min}$ in an ice-cold water bath followed by centrifugation $15,000 \times g_{n}$ for $10 \mathrm{~min}$ at $4{ }^{\circ} \mathrm{C}$. The resulting supernatant was analyzed for PG and PME activities. Total soluble protein in the supernatant was measured using the bicinchoninic acid method with bovine serum albumin as the standard (Smith et al., 1985).

Polygalacturonase activity. The endo-PG and exo-PG activities in peaches were differentiated based on the $\mathrm{pH}$ optima as reported by Pressey and Avants (1973). Endo-PG activity was assayed by mixing $250 \mu \mathrm{L}$ of cell-free protein extract with $250 \mu \mathrm{L}$ of $0.5 \%$ polygalacturonic acid (from orange peel; Sigma Chemical Co., St. Louis, MO) in $50 \mathrm{~mm} \mathrm{Na}$ acetate buffer $(\mathrm{pH} 4.4)$ and incubated at $30{ }^{\circ} \mathrm{C}$ for $16 \mathrm{~h}$ (Brummell et al., 2004) . For measurement of exo-PG activity, $250 \mu \mathrm{L}$ of enzyme extract was mixed with $250 \mu \mathrm{L}$ of $0.5 \%$ polygalacturonic acid in $50 \mathrm{~mm} \mathrm{Na}$ acetate buffer (pH 5.5) containing $2 \mathrm{~mm} \mathrm{CaCl}_{2}$ and incubated at $30{ }^{\circ} \mathrm{C}$ for $16 \mathrm{~h}$ (Zhou et al., 2000). Uronic acid reducing groups released were measured using the method of Milner and Avigad (1967) with mono-D-galacturonic acid as the standard. One unit of activity was defined as $1 \mu \mathrm{mol}$ galacturonic acid $/ \mathrm{kg} /$ protein/s.

Pectin methylesterase activity. PME activity was measured using modifications of the method of Jeong et al. (2002). A 1\% (w/v) solution of $93 \%$ esterified citrus pectin (Sigma) was prepared in $0.1 \mathrm{M} \mathrm{NaCl}$ and adjusted to $\mathrm{pH}$ 7.5 with dilute $\mathrm{NaOH}$. A $0.01 \%$ solution of bromothymol blue was prepared in $0.003 \mathrm{M}$ potassium phosphate buffer, $\mathrm{pH}$ 7.5. A 166$\mu \mathrm{L}$ volume of $1 \%$ citrus pectin was mixed with $12 \mu \mathrm{L}$ of $0.01 \%$ bromothymol blue and $70 \mu \mathrm{L}$ of water and the $\mathrm{pH}$ adjusted to 7.5 with dilute $\mathrm{NaOH}$. The reaction was initiated by adding $6 \mu \mathrm{L}$ of the cell-free protein extract that had been adjusted to $\mathrm{pH} 7.5$ with dilute $\mathrm{NaOH}$. The decrease in $A_{620}$ over a 10 -min reaction time was recorded and PME activity was expressed as $\Delta A_{620} \mathrm{~kg} / \mathrm{protein} / \mathrm{s}$.

\section{Statistical analysis}

The General Linear Model program of the Statistical Analysis System (SAS) (SAS Institute, Cary, NC) was used to detect significant differences among the maturity groups (MGs) (Figs. 1 and 2) or cultivars (Tables 1 and 2 ) at the 5\% level. Tukey's test was used for mean separation. Because there were no significance differences after ripening among the MGs for most of the qualities listed in Table 1, the data were combined for analysis. The $t$ test was used to compare qualities between 2008 and 2009. The flesh firmness 

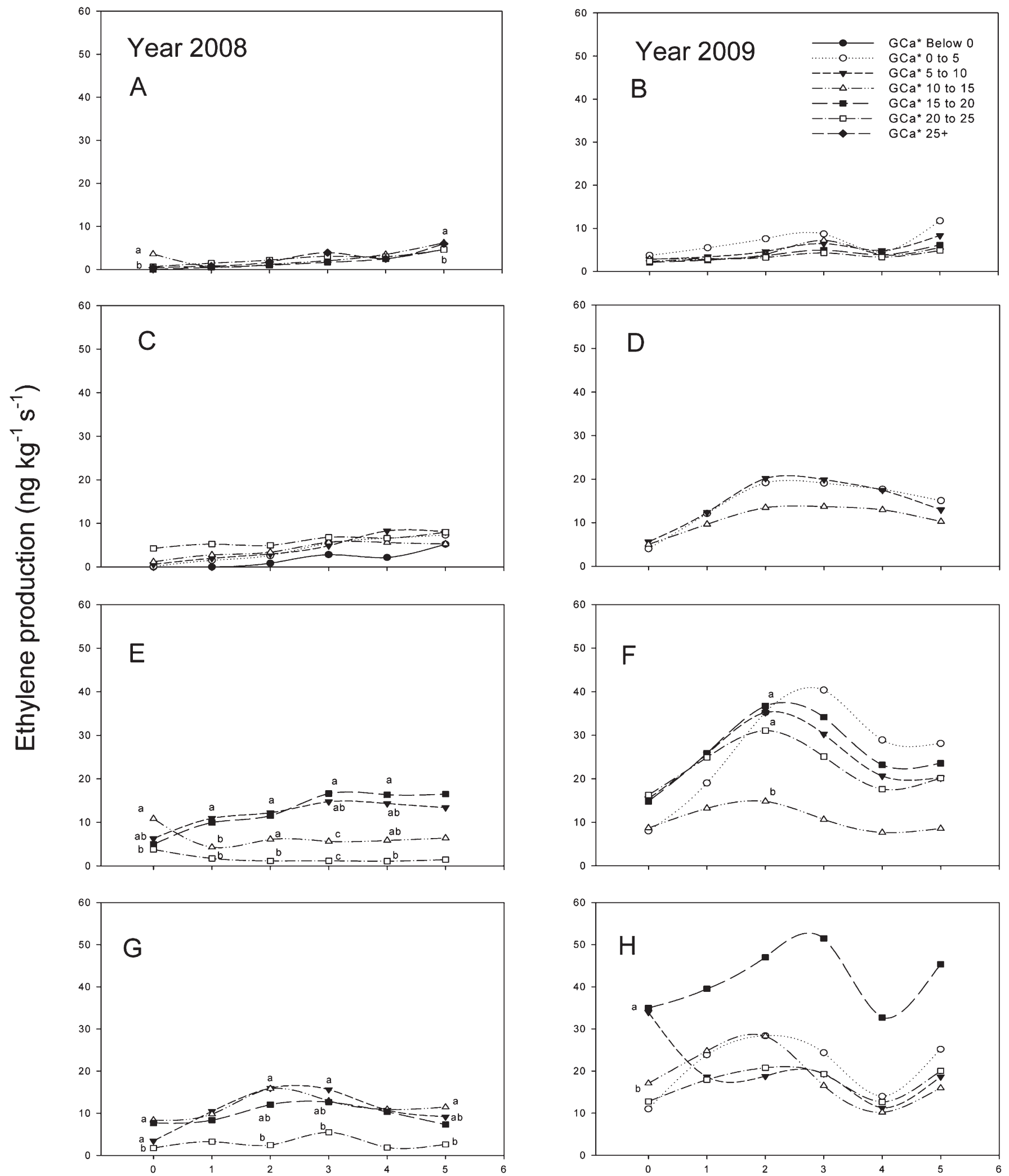

Days at $20^{\circ} \mathrm{C}$

Fig. 1. Ethylene production of MF 'Flordaprince' (A-B), MF 'TropicBeauty' (C-D), NMF 'UFSun' (E-F), and NMF 'Gulfking' (G-H) during 5 d of storage at $20{ }^{\circ} \mathrm{C}$ in 2008 and 2009. (Note: To obtain $\mu \mathrm{L} \cdot \mathrm{kg}^{-1} \cdot \mathrm{h}^{-1}$, multiply ng $\cdot \mathrm{kg}^{-1} \cdot \mathrm{s}^{-1} \times 3.1$ ). MF $=$ melting flesh; $\mathrm{NMF}=$ non-melting flesh. 

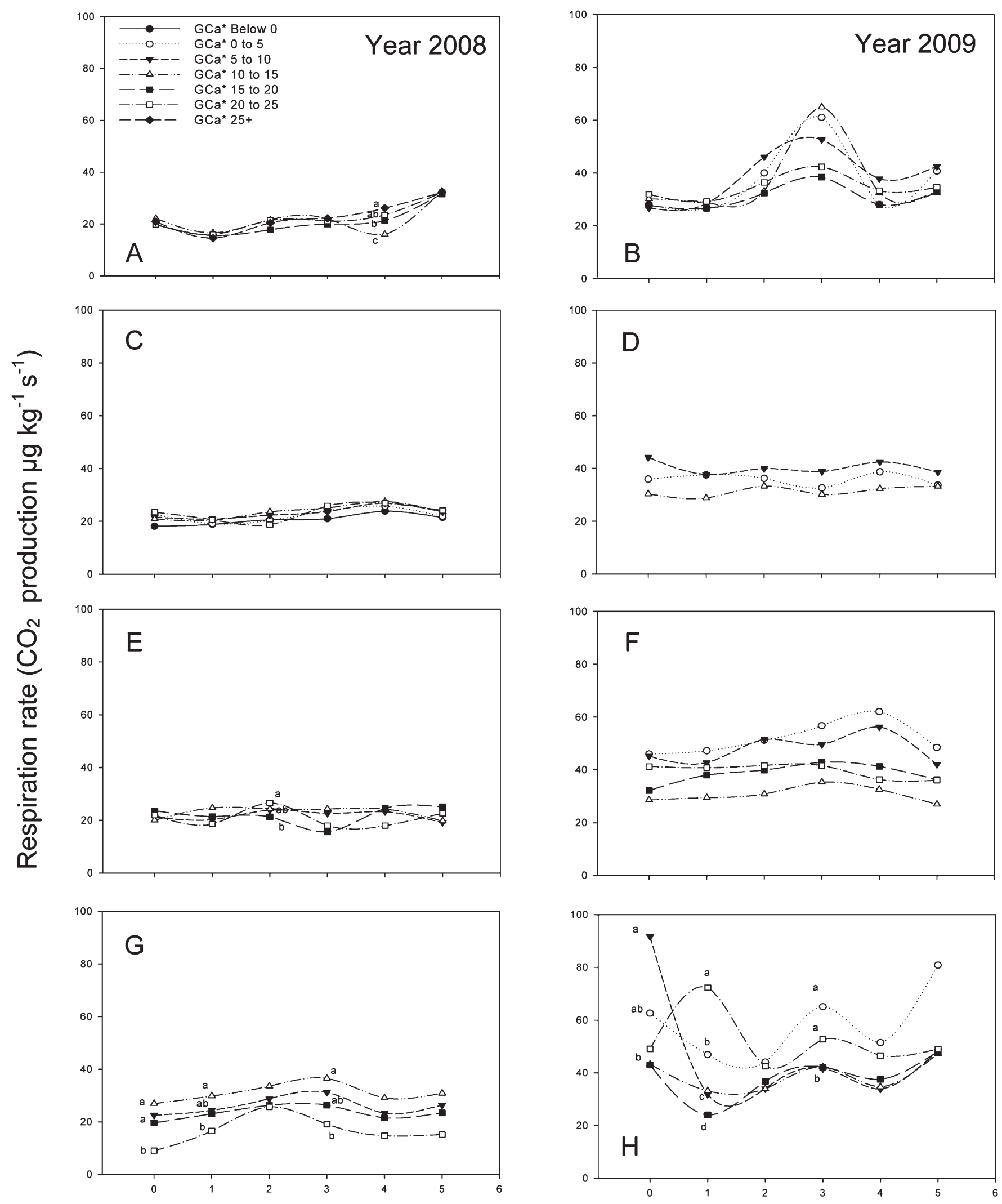

\section{Days at $20^{\circ} \mathrm{C}$}

Fig. 2. Respiration rate of MF 'Flordaprince' (A-B), MF 'TropicBeauty' (C-D), NMF 'UFSun' $(\mathbf{E}-\mathbf{F})$, and NMF 'Gulfking' $(\mathbf{G}-\mathbf{H})$ during $5 \mathrm{~d}$ of storage at $20^{\circ} \mathrm{C}$ in 2008 and 2009. (Note: To obtain $\mathrm{mg} \cdot \mathrm{kg}^{-1} \cdot \mathrm{h}^{-1}$, multiply $\mu \mathrm{g} \cdot \mathrm{kg}^{-1} \cdot \mathrm{s}^{-1} \times 3.6$ ). MF = melting flesh; $\mathrm{NMF}=$ non-melting flesh. 
Table 1. Mean fruit quality of MF and NMF peaches in 2008 and 2009 after $5 \mathrm{~d}$ of storage at $20{ }^{\circ} \mathrm{C}$ except initial $\mathrm{GCa}^{*}$, which was determined at harvest.

\begin{tabular}{lccccc}
\hline & Yr & MF ‘Flordaprince' & MF ‘TropicBeauty' & NMF ‘UFSun' & NMF ‘Gulfking' \\
\hline Initial GCa*z & 2008 & $22.97 \mathrm{a}^{\mathrm{y}}$ & $8.68 \mathrm{c}$ & $14.48 \mathrm{bc}$ & $17.49 \mathrm{ab}$ \\
& 2009 & $12.72 \mathrm{ab}$ & $6.38 \mathrm{~b}$ & $14.16 \mathrm{a}$ & $12.72 \mathrm{ab}$ \\
Final GCa*z & 2008 & $28.57 \mathrm{a}$ & $17.56 \mathrm{c}$ & $21.35 \mathrm{bc}$ & $23.87 \mathrm{ab}$ \\
& 2009 & $24.25 \mathrm{a}$ & $15.92 \mathrm{~b}$ & $23.27 \mathrm{a}$ & $21.61 \mathrm{a}$ \\
FCa*z $^{*}$ & 2008 & $8.62 \mathrm{~b}$ & $10.28 \mathrm{~b}$ & $12.43 \mathrm{ab}$ & $15.92 \mathrm{a}$ \\
& 2009 & $2.61 \mathrm{~b}$ & $9.11 \mathrm{a}$ & $8.04 \mathrm{a}$ & $6.08 \mathrm{a}$ \\
Firmness (N) & 2008 & $3.37 \mathrm{c}$ & $3.86 \mathrm{c}$ & $12.66 \mathrm{~b}$ & $17.27 \mathrm{a}$ \\
& 2009 & $2.41 \mathrm{~b}$ & $2.76 \mathrm{~b}$ & $13.99 \mathrm{a}$ & $12.74 \mathrm{a}$ \\
SSC ( ${ }^{\circ}$ Brix) & 2008 & $10.82 \mathrm{ab}$ & $12.80 \mathrm{a}$ & $9.99 \mathrm{~b}$ & $10.38 \mathrm{~b}$ \\
& 2009 & $11.16 \mathrm{ab}$ & $12.55 \mathrm{a}$ & $11.08 \mathrm{~b}$ & $10.04 \mathrm{~b}$ \\
TA (\%) & 2008 & $0.62 \mathrm{a}$ & $0.64 \mathrm{a}$ & $0.47 \mathrm{~b}$ & $0.33 \mathrm{c}$ \\
& 2009 & $0.51 \mathrm{~b}$ & $0.70 \mathrm{a}$ & $0.40 \mathrm{c}$ & $0.39 \mathrm{c}$ \\
SSC/TA & 2008 & $17.89 \mathrm{~b}$ & $20.97 \mathrm{~b}$ & $21.58 \mathrm{~b}$ & $31.55 \mathrm{a}$ \\
& 2009 & $22.16 \mathrm{bc}$ & $18.16 \mathrm{c}$ & $29.86 \mathrm{a}$ & $25.49 \mathrm{ab}$ \\
pH & 2008 & $4.23 \mathrm{~b}$ & $4.24 \mathrm{~b}$ & $4.55 \mathrm{a}$ & $4.68 \mathrm{a}$ \\
& 2009 & $4.11 \mathrm{~b}$ & $4.00 \mathrm{~b}$ & $4.64 \mathrm{a}$ & $4.56 \mathrm{a}$ \\
\hline
\end{tabular}

${ }^{2}$ Significant differences between the 2 years according to $t$ test $(P \leq 0.05)$.

${ }^{y}$ For each year, values accompanied by the same letter are not significantly different according to Tukey's test $(P \leq 0.05)$

$\mathrm{MF}=$ melting flesh $; \mathrm{NMF}=$ non-melting flesh $; \mathrm{GCa}^{*}=$ skin ground color $\mathrm{a}^{*}$ value$; \mathrm{FCa}^{*}=$ flesh color $\mathrm{a}^{*}$ value; $\mathrm{SSC}=$ soluble solids content; $\mathrm{TA}=$ titratable acidity .

Table 2. Mean flesh firmness and PG and PME activities of MF and NMF peaches after $5 \mathrm{~d}$ of storage at $20^{\circ} \mathrm{C}$ in 2007 and 2010 .

\begin{tabular}{|c|c|c|c|c|}
\hline Cultivar & $\begin{array}{c}\text { Endo-PG } \\
\text { activity } \\
\text { (units) }^{y}\end{array}$ & $\begin{array}{l}\text { Exo-PG } \\
\text { activity } \\
\text { (units) }^{\mathrm{y}}\end{array}$ & $\begin{array}{c}\text { PME } \\
\text { activity } \\
\left(\text { units } \times 10^{3}\right)^{z}\end{array}$ & Firmness $(\mathrm{N})$ \\
\hline MF Flordaprince & $1.36 \mathrm{~b}^{\mathrm{x}}$ & 1.15 & $10.02 \mathrm{a}$ & $2.43 \mathrm{~b}$ \\
\hline MF TropicBeauty & $3.85 \mathrm{a}$ & 2.42 & $7.67 \mathrm{ab}$ & $2.87 \mathrm{~b}$ \\
\hline NMF UFSun & $1.31 \mathrm{~b}$ & 0.84 & $5.00 \mathrm{bc}$ & $10.71 \mathrm{a}$ \\
\hline NMF Gulfking & $1.61 \mathrm{~b}$ & 1.26 & $2.50 \mathrm{c}$ & $10.25 \mathrm{a}$ \\
\hline Significance $(P \leq 0.05)$ & $*$ & NS & $*$ & $*$ \\
\hline
\end{tabular}

${ }^{\mathrm{z}}$ One unit of PME activity $=\Delta A_{620} \mathrm{~kg} / \mathrm{protein} / \mathrm{s}$.

${ }^{\mathrm{y}}$ One unit of $\mathrm{PG}$ activity $=1 \mu \mathrm{mol}$ galacturonic acid $/ \mathrm{kg} / \mathrm{protein} / \mathrm{s}$.

${ }^{x}$ Values accompanied by the same letter are not significantly different according to the Tukey's test $(P \leq$ $0.05)$.

*Significant.

NS $=$ nonsignificant.

$\mathrm{PG}=$ polygalacturonase $; \mathrm{PME}=$ pectin methylesterase $\mathrm{MF}=$ melting flesh $; \mathrm{NMF}=$ non-melting flesh.

and enzyme activities listed in Table 2 were presented as averages of the two seasons as a result of no significant differences being detected between the seasons.

\section{Results and Discussion}

\section{Respiration and ethylene production}

In 2008 and 2009, fruit from all the MGs of both MF 'Flordaprince' and MF 'TropicBeauty' were preclimacteric at the time of harvest as shown by increasing ethylene production and respiration rate measured after harvest (Figs. 1A-1D and 2A-2D). The ethylene production measured at harvest indicates that the MF cultivars only required low levels of ethylene to initiate ripening, because the fruit were apparently producing minimal amounts of ethylene on the tree. Fruit from different MGs were generally not significantly different in ethylene production and respiration rate for both MF cultivars, indicating that most of fruit had reached physiological maturity at the time of harvest. The ethylene production rates at harvest and during ripening at $20{ }^{\circ} \mathrm{C}$ in 2008 for 'TropicBeauty' from the most mature to the least mature fruit were similar to values reported by Brovelli et al. (1998) for that cultivar. Although respiration rates during ripening for 'TropicBeauty' in both 2008 and 2009 were higher than previously reported values, the trends were comparable (Brovelli et al., 1999a).

The NMF cultivars generally had higher peak rates of ethylene production than the MF cultivars during ripening, confirming that the NMF trait in peaches is not related to low ethylene production (Brovelli et al., 1999a, 1999b; Manganaris et al., 2006). For NMF 'UFSun', fruit with $\mathrm{GCa}^{*}$ values of 10 to 15 and 20 to 25 were postclimacteric at the time of harvest in 2008, indicating that fruit from the more advanced MGs were undergoing the climacteric on the tree before harvest (Fig. 1E). In contrast, a trend of increasing (i.e., climacteric) ethylene production was observed in 2009 for 'UFSun' fruit on being placed in storage (Fig. 1F). This suggests that there was a difference in harvest maturity between 'UFSun' fruit in 2008 and 2009. For NMF 'Gulfking' peaches, ethylene production was postclimacteric in fruit of $\mathrm{GCa}^{*} 20$ to 25 in 2008, but none of the MGs were postclimacteric in 2009 (Fig. 1G-1H). However, the respiration peaks of fruit with $\mathrm{GCa}^{*}$ of 20 to 25 occurred 1 and $2 \mathrm{~d}$ in advance compared with that of fruit from the lower MGs in 2008 and 2009, respectively (Fig. 2G-2H).
Therefore, 'Gulfking' fruit with $\mathrm{GCa}^{\text {* }}$ 20 to 25 reached the postclimacteric stage during storage.

\section{Quality analysis}

Skin ground color ( $\left.\mathrm{GCa}^{*}\right)$ increased markedly during $5 \mathrm{~d}$ of storage at $20^{\circ} \mathrm{C}$ (Table 1 ; $P \leq 0.05)$. In peaches, the increase in $\mathrm{a}^{*}$ denotes an increase in carotenoid pigments and a loss of green color that is related to the disappearance of chlorophyll (Ferrer et al., 2005; Madrid et al., 2000). The initial GCa* and final $\mathrm{GCa}^{*}$ of 'TropicBeauty' peaches were the lowest among all the cultivars in both 2008 and $2009(P \leq 0.05)$, indicating that this MF cultivar generally has less carotenoid accumulation in the skin than the other cultivars that were included in this study. MF 'Flordaprince' had the lowest $\mathrm{FCa}^{*}$ compared with the other cultivars $(P \leq 0.05)$, reflecting the fact that its mesocarp is more yellow than orange compared with the other cultivars.

It has been reported that MF peaches at the eating ripe stage should be close to $13 \mathrm{~N}$ flesh firmness, $0.5 \%$ to $0.8 \%$ TA, and at least $10 \% \mathrm{SSC}$ or SSC/TA 15 or greater for best eating quality (Malakou and Nanos, 2005; Robertson et al., 1990). Currently, no criteria for minimum eating quality have been defined for NMF peaches, although it is known that a ripe NMF fruit may soften to $\approx 16 \mathrm{~N}$ in firmness (Lurie and Crisosto, 2005). The MF peaches in this study became extremely soft during storage (flesh firmness less than $4 \mathrm{~N}$ ) and the NMF peaches retained greater flesh firmness for longer than the MF peaches. Both NMF cultivars maintained flesh firmness greater than $12 \mathrm{~N}$ after ripening for $5 \mathrm{~d}$ at $20{ }^{\circ} \mathrm{C}$.

A SSC/TA ratio 15 or greater was consistently observed in all the cultivars in this study (Table 1), suggesting that all four of the cultivars would be perceived as having desirable sensory quality. MF 'TropicBeauty' had the highest SSC in the 2 years of this study $(12.55 \%$ to $12.80 \% ; P \leq 0.05)$. Interestingly, although the higher SSC of 'TropicBeauty' was somewhat balanced by higher TA, the lower SSC of the NMF cultivars was greatly offset by lower TA, resulting in higher SSC/TA values than either MF cultivar (Table 1; $P \leq 0.05$ ). Brovelli et al. (1999b) reported that there were no clear distinctions between the sensory aspects of MF and NMF peaches except texture after normal ripening. Because TA was significantly different between the MF and NMF cultivars in this study, TA could also be a major factor influencing the sensory aspects of peaches. Consumers reportedly prefer low-acid over high-acid cultivars regardless of fruit maturity (Iglesias and Echeverria, 2009). Therefore, consumers may perceive NMF 'Gulfking' most favorably among the cultivars studied because it consistently had relatively high SSC/TA as a result of it having the lowest TA over the two seasons. The MF cultivars consistently had lower $\mathrm{pH}$ than the NMF cultivars after ripening. It has been shown that $\mathrm{pH}$ can sometimes relate better to sourness perception 
than TA in mangoes (Malundo et al., 2001). Hence, the MF cultivars might be expected to be perceived as more sour than the NMF cultivars.

\section{Polygalacturonase and pectin methylesterase assays}

MF 'TropicBeauty' had the highest level of endo-PG activity among the four cultivars after being stored at $20^{\circ} \mathrm{C}$ for $5 \mathrm{~d}$ (Table 2). The endo-PG activity of NMF 'UFSun' and NMF 'Gulfking' was no different from that of the MF 'Flordaprince' (Table 2), but the firmness values of the NMF cultivars were approximately five times greater than for MF 'Flordaprince' (Table 2). Because MF and NMF cultivars can have similar endo-PG activities, lack of endo-PG mRNA accumulation of NMF peaches may not fully explain their delayed softening characteristics as suggested by Callahan et al. (2004). Rather, our results confirm the report of Morgutti et al., (2006), who observed that although NMF 'OroA' peaches showed barely detectable accumulation of endo-PG polypeptide and MF 'Bolero' showed much higher endo-PG accumulation, the two cultivars had essentially the same flesh firmness (46 N). It may also be possible that the standard firmness measurement procedure using a MagnessTaylor type probe, which was developed for MF peaches, does not accurately measure the different texture of NMF peaches.

Fruit of the NMF cultivars were not characterized by higher exo-PG activities compared with the MF cultivars after storage (Table 2). This contrasts with the report of Manganaris et al. (2006) who reported higher exo-PG activity in NMF 'Andross' peaches than in MF 'Caldesi 2000' nectarines. Exo-PG activities of the four cultivars at full ripeness stage were not found to be significantly different in our study. Therefore, exo-PG activity may not be a particularly robust indicator for characterization of different peach fruit textures.

The PME activity of the NMF peaches was generally lower than that of the MF peaches after storage (Table 2; $P \leq 0.05$ ), which is in agreement with the results of Manganaris et al. (2006). The lower PME activity of the NMF peaches could limit the generation of substrate for endo-PG because de-methylesterification is a prelude to PGmediated pectin disassembly (Muramatsu et al., 2004; Wakabayashi et al., 2000). Hence, the level of PME activity may be more directly related to the flesh firmness of the peach fruit during ripening than the endo-PG activity.

\section{Conclusion}

Texture was significantly different in all four seasons and TA was significantly different in both seasons that it was measured between the MF and NMF cultivars after ripening for $5 \mathrm{~d}$ at $20^{\circ} \mathrm{C}$. The NMF cultivars retained greater flesh firmness than the MF cultivars after ripening. Delaying harvesting of the NMF peaches until $\mathrm{GCa}^{*} 5$ to 10 for 'UFSun' and GCa* 15 to 20 for 'Gulfking' were achieved and would allow tree-ripe fruit to be marketed while avoiding fruit that would quickly become postclimacteric during storage. The MF peaches in our study could be perceived as more acidic than the NMF peaches after ripening as a result of their higher TA and lower $\mathrm{pH}$. Because the MF peaches became extremely soft during ripening, delaying their harvest to obtain lower TA for higher consumer acceptance might not be possible. Finally, neither endo-PG nor exo-PG activities showed a quantitative relationship with the flesh firmness of peaches during ripening. The level of PME activity appears to be more directly related to degree of softening in peaches, probably by regulating the availability of substrate for endo-PG.

\section{Literature Cited}

Amoros, A., M. Serrano, F. Riguelme, and F. Romojaro. 1989. Levels of ACC and physical and chemical parameters in peach development. J. Hort. Sci. 64:673-677.

Bakshi, P. and F.A. Masoodi. 2009. Effect of various storage conditions on chemical characteristics and processing of peach cv. 'Flordasun'. J. Food Sci. Technol. 46:271-274.

Brovelli, E.A., J.K. Brecht, W.B. Sherman, and C.A. Sims. 1998. Potential maturity indices and developmental aspects of melting-flesh and nonmelting-flesh peach genotypes for the fresh market. J. Amer. Soc. Hort. Sci. 123:438-444.

Brovelli, E.A., J.K. Brecht, W.B. Sherman, and C.A. Sims. 1999a. Nonmelting-flesh trait in peaches is not related to low ethylene production rates. HortScience 34:313-315.

Brovelli, E.A., J.K. Brecht, W.B. Sherman, C.A Sims, and J.M. Harrison. 1999b. Sensory and compositional attributes of melting- and nonmelting-flesh peaches for the fresh market. J. Sci. Food Agr. 79:707-712.

Brummell, D.A., V. Dal Cin, C.H. Crisosto, and J.M. Labavitch. 2004. Cell wall metabolism during maturation, ripening and senescence of peach fruit. J. Expt. Bot. 55:2029-2039.

Callahan, A., R. Scorza, C. Bassett, M. Nickerson, and F. Abeles. 2004. Deletions in an endopolygalacturonase gene cluster correlate with non-melting flesh texture in peach. Funct. Plant Biol. 31:159-168.

Cascales, A., E. Costell, and F. Romojaro. 2005. Effects of the degree of maturity on the chemical composition, physical characteristics and sensory attributes of peach (Prunus persica) cv. Caterin. Food Sci. Technol. Intl. 11:345-352.

Crisosto, C.H. and G.M. Crisosto. 2005. Relationship between ripe soluble solids concentration (RSSC) and consumer acceptance of high and low acid melting flesh peach and nectarine [Prunus persica (L.) Batsch] cultivars. Postharvest Biol. Technol. 38:239-246.

Crisosto, C.H., G.M. Crisosto, G. Echeverria, and J. Puy. 2006. Segregation of peach and nectarine [Prunus persica (L.) Batsch] cultivars according to their organoleptic characteristics. Postharvest Biol. Technol. 39:10-18.

Crisosto, C.H., D. Garner, G.M. Crisosto, and E. Bowerman. 2004. Increasing 'Blackamber' plum (Prunus salicina Lindell) consumer acceptance. Postharvest Biol. Technol. 24:237244.

Delwiche, M.J. and R.A. Baumgardner. 1983. Ground color measurements of peach. J. Amer. Soc. Hort. Sci. 108:1012-1016.

Delwiche, M.J. and R.A. Baumgardner. 1985. Ground color as a peach maturity index. J. Amer. Soc. Hort. Sci. 110:53-57.
Downs, C.G. and C.J. Brady. 1990. Two forms of exopolygalacturonase increase as peach fruits ripen. Plant Cell Environ. 13:523-530.

Ferrer, A., S. Remon, A.I. Negueruela, and R. Oria. 2005. Changes during the ripening of the very late season Spanish peach cultivar Calanda. Feasibility of using CIELAB coordinates as maturity indices. Sci. Hort. 105:435-446.

Fischer, R.L. and A.B. Bennett. 1991. Role of cell wall hydrolases in fruit ripening. Annu. Rev. Plant Physiol. Plant Mol. Biol. 42:675-703.

Fuleki, T. and F.I. Cook. 1976. Relationship of maturity as indicated by flesh color to quality of canned clingstone peaches. J. Inst. Can. Sci. Technol. 9:43-46.

Glover, H. and C. Brady. 1995. Pectinesterases from mature, unripe peach fruit bind strongly to pectic polysaccharides. Aust. J. Plant Physiol. 22:977-985.

Hadfield, K.A. and A.B. Bennett. 1998. Polygalacturonases: Many genes in search of a function. Plant Physiol. 117:337-343.

Iglesias, I. and G. Echeverria. 2009. Differential effect of cultivar and harvest date on nectarine colour, quality and consumer acceptance. Sci. Hort. 120:41-50.

Jeong, J., D.J. Huber, and S.A. Sargent. 2002. Influence of 1-methylcyclopropene (1-MCP) on ripening and cell-wall matrix polysaccharides of avocado (Persea americana) fruit. Postharvest Biol. Technol. 25:241-256.

Kader, A., C. Heintz, and A. Chordas. 1982. Postharvest quality of fresh and canned clingstone peaches as influenced by genotypes and maturity at harvest. J. Amer. Soc. Hort. Sci. 107:947951.

Kwon, J.H., J.H. Jun, and H.J. Lee. 2007. Changes in sugar composition and related enzyme activities during fruit development in 'Kansuke Hakuto' and 'Kurakatawase' peach (Prunus persica). Hort. Environ. Biotechnol. 48:235240.

Lester, D.R., W.B. Sherman, and B.J. Atwell. 1996. Endopolygalacturonase and the melting flesh (M) locus in peach. J. Amer. Soc. Hort. Sci. 121:231-235.

Lester, D.R., J. Speirs, G. Orr, and C.J. Brady. 1994. Peach (Prunus persica) endopolygalacturonase cDNA isolation and mRNA analysis in melting and nonmelting peach cultivars. Plant Physiol. 105:225-231.

Lurie, S. and C.H. Crisosto. 2005. Chilling injury in peach and nectarine. Postharvest Biol. Technol. 37:195-208.

Madrid, M., M. Serrano, M. Pretel, G. MartinezReina, and F. Romojaro. 2000. The ripening of Prunus persica fruits with a dominant flat allele. Food Sci. Technol. Intl. 6:399-405.

Malakou, A. and G.D. Nanos. 2005. A combination of hot water treatment and modified atmosphere packaging maintains quality of advanced maturity 'Caldesi 2000' nectarines and 'Royal Glory' peaches. Postharvest Biol. Technol. 38:106-114.

Malundo, T.M.M., R.L. Shewfelt, G.O. Ware, and E.A. Baldwin. 2001. Sugars and acids influence flavor properties of mango (Mangifera indica). J. Amer. Soc. Hort. Sci. 126:115-121.

Manganaris, G.A., M. Vasilakakis, G. Diamantidis, and I. Mignani. 2006. Diverse metabolism of cell wall components of melting and nonmelting peach genotypes during ripening after harvest or cold storage. J. Sci. Food Agr. $86: 243-250$.

Milner, Y. and G. Avigad. 1967. A copper reagent for the determination of hexuronic acids and certain ketohexoses. Carbohydr. Res. 112:359361. 
Moing, A., L. Svanella, D. Rolin, M. Gaudillere, J.P. Gaudillere, and R. Monet. 1998. Compositional changes during the fruit development of two peach cultivars differing in juice acidity. J. Amer. Soc. Hort. Sci. 123:770-775.

Morgutti, S., N. Negrini, F. Nocito, A. Ghiani, D. Bassi, and M. Cocucci. 2006. Changes in endopolygalacturonase levels and characterization of a putative endo-PG gene during fruit softening in peach genotypes with nonmelting and melting flesh fruit phenotypes. New Phytol. 171:315-328.

Muramatsu, N., K. Tanaka, T. Asakura, and T. Haji. 2004. Changes in cell wall polysaccharides and physical properties of peach (Prunus persica Batsch) fruit during ripening. J. Jpn. Soc. Hort. Sci. 73:534-540.

Orr, G. and C. Brady. 1993. Relationship of endopolygalacturonase activity to fruit softening in a freestone peach. Postharvest Biol. Technol. 3:121-130.

Peace, C.P., C.H. Crisosto, and T.M. Gradziel. 2005. Endopolygalacturonase: A candidate gene for freestone and melting flesh in peach. Mol. Breed. 16:21-31.

Pressey, R. and J.K. Avants. 1973. Separation and characterization of endopolygalacturonase and exopolygalacturonase from peaches. Plant Physiol. 52:252-256.

Pressey, R. and J.K. Avants. 1978. Difference in polygalacturonase composition of clingstone and freestone peaches. J. Food Sci. 43:1415-1417.

Robertson, J.A., R.J. Horvat, B.G. Lyon, F.I. Meredith, S.D. Senter, and W.R. Okie. 1990 Comparison of quality characteristics of selected yellow-and white-fleshed peach cultivars. J. Food Sci. 55:1308-1311.

Robertson, J.A., F.I. Meredith, and W.R. Forbus. 1991. Changes in quality characteristics during peach (cv Majestic) maturation. J. Food Qual. 14:197-207.

Robertson, J.A., F.I. Meredith, B.G. Lyon, G.W. Chapman, and W.B. Sherman. 1992. Ripening and cold-storage changes in the quality characteristics of nonmelting clingstone peaches (Fla 9-20c). J. Food Sci. 57:462-465.
Smith, P.K., R.I. Krohn, G.T. Hermanson, A.K. Mallia, F.H. Gartner, M.D. Provenzano, E.K. Fujimoto, N.M. Goeke, B.J. Olson, and D.C. Klenk. 1985. Measurement of protein using biccinchoninic acid. Anal. Biochem. 150:7685.

Wakabayashi, K., J.P. Chun, and D.J. Huber. 2000. Extensive solubilization and depolymerization of cellwall polysaccharides during avocado (Persea americana) ripening involves concerted action of polygalacturonase and pectinmethylesterase. Physiol. Plant. 108:345-352.

Williamson, J.G. and S.A. Sargent. 1999. Postharvest characteristics and consumer acceptance of non-melting peaches. Proc. Fla. State Hort. Soc. 112:241-242.

Zhou, H.W., L. Sonego, A. Khalchiski, R. BenArie, A. Lers, and S. Lurie. 2000. Cell wall enzymes and cell wall changes in 'Flavortop' nectarines: MRNA abundance, enzyme activity, and changes in pectic and neutral polymers during ripening and in woolly fruit. J. Amer. Soc. Hort. Sci. 125:630-637. 